\title{
Allograft versus autograft for pediatric posterior cervical and occipito-cervical fusion: a systematic review of factors affecting fusion rates
}

\author{
Stephen L. Reintjes, MD, ${ }^{1,3}$ Ernest K. Amankwah, PhD, ${ }^{2}$ Luis F. Rodriguez, MD, ${ }^{1,3}$ \\ Carolyn C. Carey, MD, ${ }^{1,3}$ and Gerald F. Tuite, MD1,3,4
}

${ }^{1}$ Neuroscience Institute, and 2Department of Clinical and Translational Research, All Children's Hospital/Johns Hopkins Medicine, St. Petersburg; ${ }^{3}$ Department of Neurosurgery and Brain Repair, Morsani College of Medicine, University of South Florida, Tampa, Florida; and ${ }^{4}$ Department of Pediatrics, Johns Hopkins School of Medicine, Baltimore, Maryland

OBJECTIVE Fusion rates are high for children undergoing posterior cervical fusion (PCF) and occipito-cervical fusion (OCF). Autologous bone has been widely used as the graft material of choice, despite the risk of donor-site morbidity associated with harvesting the bone, possibly because very low fusion rates were reported with posterior allograft cervical fusions in children several decades ago. Higher overall fusion rates using allograft in adults, associated with improvements in internal fixation techniques and the availability of osteoinductive substances such as bone morphogenetic protein (BMP), have led to heightened enthusiasm for the use of bank bone during pediatric PCF. A systematic review was performed to study factors associated with successful bone fusion, including the type of bone graft used.

METHODS The authors performed a comprehensive PubMed search of English-language articles pertaining to PCF and OCF in patients less than 18 years old. Of the 561 abstracts selected, 148 articles were reviewed, resulting in 60 articles that had sufficient detail to be included in the analysis. A meta-regression analysis was performed to determine if and how age, fusion technique, levels fused, fusion substrate, BMP use, postoperative bracing, and radiographic fusion criteria were related to the pooled prevalence estimates. A systematic review of the literature was performed according to the PRISMA (Preferred Reporting Items for Systematic Reviews and Meta-Analyses) statement.

RESULTS A total of 604 patients met the specific inclusion and exclusion criteria. The overall fusion rate was $93 \%$, with a mean age of 9.3 years and mean follow-up of 38.7 months. A total of 539 patients had fusion with autograft $(94 \%$ fusion rate) and 65 patients with allograft ( $80 \%$ fusion rate). Multivariate meta-regression analysis showed that higher fusion rates were associated with OCF compared with fusions that excluded the occiput $(p<0.001)$, with the use of autograft instead of allograft $(p<0.001)$, and with the use of $C T$ to define fusion instead of plain radiography alone. The type of internal fixation, the use of BMP, patient age, and the duration of follow-up were not found to be associated with fusion rates in the multivariate analysis.

CONCLUSIONS Fusion rates for PCF are high, with higher rates of fusion seen when autograft is used as the bone substrate and when the occiput is included in the fusion construct. Further study of the use of allograft as a viable alternative to autograft bone fusion is warranted because limited data are available regarding the use of allograft in combination with more rigid internal fixation techniques and osteoinductive substances, both of which may enhance fusion rates with allograft.

http://thejns.org/doi/abs/10.3171/2015.6.PEDS1562

KEY WORDS cervical; occipital; fusion; allograft; bone morphogenetic protein; pediatric; spine

A UTOLOGOUs bone has long been considered the "gold standard" bone source for posterior cervical fusion $(\mathrm{PCF})$ in adult and pediatric patients, despite the fact that multiple studies over the past several decades have shown that allograft bone materials produce very high fusion rates in other parts of the spine, while eliminating donor-site morbidity. ${ }^{46,50,62,138}$ While allogenic bone graft material does not offer the osteogenic, osteoinductive advantages of autograft, the use of allogenic bank bone has produced very high spinal fusion rates overall throughout the rest of the spine, particularly when rigid internal fixation techniques are used. ${ }^{93,114}$

ABBREVIATIONS BMP = bone morphogenetic protein; $F E=$ flexion and extension; $I C=$ iliac crest; $O C F=$ occipito-cervical fusion; $P C F=$ posterior cervical fusion. SUBMITTED January 27, 2015. ACCEPTED June 3, 2015.

INCLUDE WHEN CITING Published online October 23, 2015; DOI: 10.3171/2015.6.PEDS1562. 
The complications associated with the use of autograft are well known, including longer operative times, postoperative pain, increased blood loss, increased infection risk, seroma formation, pelvic fracture, the risk of peripheral nerve injury, and donor site pain, which can be long lasting. ${ }^{87,93,126}$ These complications are particularly troublesome in young children, making the use of allograft even more appealing in the pediatric population. These concerns, combined with the robust propensity for fusion in young children, led surgeons to embrace the concept of allograft use during PCF in the pediatric population once safe sources of allogenic bone became available many years ago. ${ }^{68,82,138}$

Even though the use of allograft seems ideally suited for PCF in children, initial reports published over 30 years ago were associated with very low fusion rates..$^{68,82,138}$ These disappointing early results with allograft alone, without autologous bone grafting, contributed to the widespread teaching of spine surgeons that PCF in children should be performed with autologous bone graft as the primary fusion substrate. ${ }^{46,50,62,138}$ However, more recently, surgeons have been emboldened to once again attempt to use allograft alone based on higher fusion rates associated with more rigid internal fixation techniques, the availability of osteoinductive substances such as bone morphogenetic protein (BMP), and the high fusion rates recently reported in adults who have undergone PCF using allograft alone.

We chose to perform a systematic review of the available medical literature related to fusion rates in patients less than 18 years of age who had undergone PCF, with or without inclusion of the occiput. Our primary objective was to determine the relative fusion rates using allograft compared with autologous bone graft, while also considering the effect of other study variables.

\section{Methods}

A literature search was performed using PubMed for English-language articles with the keywords "allograft," "autograft," "graft," "atlantoaxial," "occipito-cervical fusion," "cervical instability," "C1-2 instability," "os odontoideum," and "fusion." The systematic review was carried out according to the PRISMA (Preferred Reporting Items for Systematic Reviews and Meta-Analyses) statement. ${ }^{130}$ To be included in our analysis, the abstract needed to be in the English language and have information regarding PCF and/or occipito-cervical fusion (OCF). From this initial search, a total of 561 abstracts were selected, dating from January 1966 to July 2014. From these 561 abstracts, we selected 148 full-text articles for further review, selecting only those articles that may have had information regarding PCF or OCF in at least 1 patient who was less than 18 years of age.

Two authors (S.L.R., G.F.T.) independently reviewed each of the 148 journal articles. Articles were eliminated from consideration if they did not satisfy each of the inclusion criteria: information concerning PCF or OCF in at least 1 patient who was younger than 18 years of age, specific data regarding the fusion construct and fusion rates, the type of graft material used, and sufficient follow-up for the authors of the articles to determine if a successful fusion had taken place. We included patients who had less than 1 year of follow-up if a successful fusion was documented. If follow-up was less than 1 year and no fusion was documented, we excluded that patient from the analysis. Papers that did not provide detailed information concerning all the inclusion criteria, such as technical notes or broad review papers without individual patient data, were excluded from the statistical review. If both reviewers agreed that a study met all the inclusion and exclusion criteria, the study was included in our analysis. If the reviewers disagreed, they reviewed the article together and made a joint decision about its inclusion. Eighty-eight articles did not meet the specific criteria for inclusion and were consequently excluded from this study. These articles are listed in Table 1.

Of the 148 articles reviewed, 60 articles met the inclusion criteria for a total of 604 patients included in the review. Many of the articles described a heterogeneous group of patients, with great variation within each paper regarding patient age, the method of internal fixation, the type of bone graft used, the method of postoperative external orthosis, and the radiographic method used for assessing fusion. For this reason, individual patient data were separated in a large data sheet to distinguish between patients with similar variables from those who were managed differently. For example, groups of patients within each article with similar fusion techniques, bone source, BMP use, postoperative orthosis, and method of radiographic follow-up were separated from those with dissimilar management strategies. By separating patients in this way, we could independently analyze each variable.

Data regarding age, internal fixation technique, graft type (autograft vs allograft), bone source, levels of fusion, the use of BMP, the type of postoperative orthosis, and the duration of follow-up were recorded. Two main groups were distinguished according to internal fixation techniques of the fusion construct: those who underwent nonrigid techniques and those who underwent more modern screw techniques. Onlay fusion and wiring were considered nonrigid constructs (primary wiring). Transarticular screws, screw/rod, and screw/plate internal fixation techniques were considered rigid constructs (primary screws).

Individual patient data regarding the bone substrate used was also documented. A fusion was considered done with autologous bone if bone graft was harvested and used for the fusion, with or without the use of allograft to supplement the fusion construct. A patient was considered in the allograft group if the fusion was done primarily with allograft bone material or bone substitutes, without separately harvesting autologous bone graft. Typical autologous bone graft sources included iliac crest (IC), skull, rib, spinous process, femur, or tibia/fibula. We considered allograft to include cancellous bone chips, freeze-dried cortical bone, or calcium hydroxyapatite.

The use of recombinant human BMP-2 was also recorded. If the use of BMP was not specifically stated in the article, we recorded "no" if the paper was published before 2001. If there was no mention of BMP use in a paper published after 2001, we contacted the authors to determine if they had used BMP or not. If clarification was 
TABLE 1. Eighty-eight papers reviewed but eliminated from the systematic review because key data were missing
Ain et al., 2006

Anakwenze et al., 2011

Anderson et al., 2007

Arkader et al., 2007

Aryan et al., 2008

Bailey et al., 1969

Bisson et al., 2010

Bollo et al., 2012

Brockmeyer et al., 1995

Buttermann et al., 1996

Chamoun et al., 2009

Chen et al., 2005

Couture et al., 2010

Crostelli et al., 2009

Dede et al., 2013

Deutsch et al., 2007

Dickerman et al., 2005

Dormans et al., 1995

Duhem et al., 2008

Dzenitis et al., 1966

Eleraky et al., 2000

Elliott et al., 201238

Elliott et al., 201239

Elliott et al., 201440

Elliott et al., 201441

Fahim et al., 2010

Fargen et al., 2011

Fenoy et al., 2008

Fielding et al., 1976

Fielding et al., 1987

Fuchs et al., 2001

Garg et al., 2003

Goel et al., 2013

Govender et al., 2001

Griswold et al., 1978

Hamblen et al., 1967

Hamilton et al., 2011

Hardy et al., 1985

Harrington et al., 2007

Hedequist et al., 2010

Hedequist et al., 2008

Heilman et al., 2001

Heuer et al., 2009

Hillard et al., 2009
Ahmed et al., 2008
Hood et al., 2013

Hooley et al., 2006

Jackson et al., 1999

Jandali et al., 2011

Kalra et al., 2007

Kang et al., 2012

Lee et al., 2012

Lee et al., 1997

Lekovic et al., 2006

Lementowski et al., 2010

Lubelski et al., 2014

Martus et al., 2011

Mummaneni et al., 2010

Nakagawa et al., 1997

$\mathrm{Ni}$ et al., 2012

Nockels et al., 2007

Pang et al., 2010

Pang et al., 2005

Pang et al., 2007

Parker et al., 2009

Peng et al., 2011

Rao et al., 1990

Robertson et al., 1998

Rodgers et al., 1999

Rodgers et al., 1997

Roy et al., 1970

Rozzelle et al., 2013

Sakou et al., 1989

Sawin et al., 1998

Shin et al., 2006

Simsek et al., 2009

Steinmetz et al., 2003

Tauchi et al., 2012

Thomas et al., 2010

Tsirikos et al., 2007

Tubbs et al., 2011

Tubbs et al., 2002

Tuli et al., 2004

Vaccaro et al., 2002

Wang et al., 2012

Wills et al., 2006

Yerramneni et al., 2011

Zenonos et al., 2012

Zhang et al., 2013 not possible by contacting the authors, we recorded BMP use as "presumed no" (designated by asterisk in Tables 2-4) if there was no mention of BMP use in a paper published after 2001.

Radiographic criteria and the assessment of fusion success varied and were not standardized among all studies. Imaging criteria determining successful fusion included plain radiographs, flexion and extension (FE) radiographs, and CT imaging. Successful reports of fusion were based on each author's interpretation of the imaging results.
There is much variation in fusion criteria among authors, with earlier studies evaluating fusion with different methods from those of the recent literature. We qualified fusion based on the original author's best assessment, regardless of imaging modality, whether it was plain radiography, FE radiography, or CT. Fusion rates were documented only when the article clearly stated that fusion was documented radiographically. All patients included in this review had a reported fusion status as "fused" or "not fused."

\section{Statistical Analysis}

Statistical analyses were conducted using $\mathrm{R}$ version 3.0.0 (www.r-project.org), and a $\mathrm{p}$ value $<0.05$ was considered statistically significant. ${ }^{115}$ We tested heterogeneity among study effect sizes with Cochran's Q test and quantified heterogeneity by $\mathrm{I}^{2}$ with $\mathrm{I}^{2} \leq 25 \%, \mathrm{I}^{2} \approx 50 \%$, and $\mathrm{I}^{2} \geq$ $75 \%$ indicating low, medium, and high heterogeneity, respectively. ${ }^{65}$ We used the fixed effects model to calculate pooled estimates and $95 \%$ CI for fusion prevalence because heterogeneity between studies was moderate $\left(\mathrm{I}^{2}=26.9 \%\right)$.

Publication bias was assessed graphically using funnel plots and Egger's regression asymmetry test. To further explore the sources of between-study heterogeneity, we performed a meta-regression analysis examining if and how fusion technique, levels fused, fusion substrate, BMP use, postoperative bracing, and radiographic fusion criteria were related to the pooled prevalence estimates. Factors that had a $\mathrm{p}$ value $<0.1$ in the univariate analysis were included in a multivariate regression model.

\section{Results}

The detailed review of 60 full-text articles resulted in the analysis of 604 patients who underwent PCF or OCF before 18 years of age. Fifty-three papers described 539 patients who underwent PCF or OCF using autograft. Fourteen papers described 65 patients who underwent PCF or OCF using allograft, without autologous bone grafting (Fig. 1, Tables 2-6).

The data are presented in the tables and are stratified by fusion location (occipito-cervical vs cervical), fixation technique (primary wiring vs primary screw), and bone graft type (autograft vs allograft). Table 2 describes studies that evaluated OCF using autologous bone grafts; Table 3 summarizes papers that describe PCF (not including the occiput) with autologous bone graft, and Table 4 summarizes papers that describe patients who had OCF or PCF using allograft. Table 5 compares overall PCF and OCF rates with autologous bone graft versus allograft, with or without rigid fixation. Table 6 shows the results of our multivariate meta-regression analysis for the prevalence of pediatric patients who had a successful posterior $\mathrm{OCF}$ or PCF.

\section{Posterior OCF Cohort}

OCF performed with nonrigid internal fixation (primary wiring) was represented as follows: autologous bone was used in 188 patients described in 25 studies (Table 2); allograft was used in only 2 patients described in 2 studies (Table 4). OCF using rigid fixation (primary screw) was represented as follows: autologous bone was used in 135 


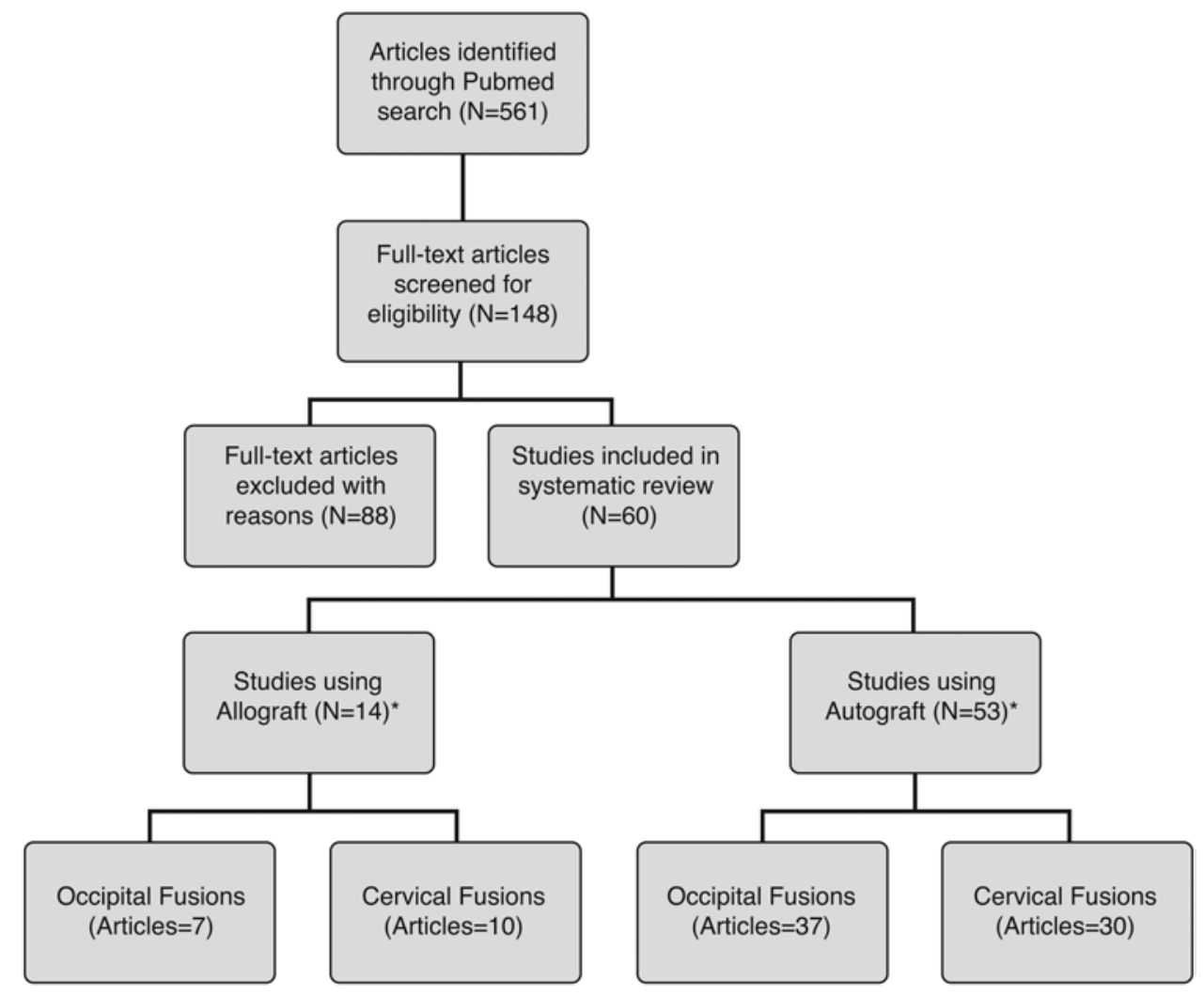

FIG. 1. Flow diagram summarizing the literature review for the systematic review of published articles related to pediatric PCF. There is overlap in the number of articles in each category because articles frequently included patients with OCF and PCF and/ or the use of allograft and autograft. Asterisks indicate that patients were stratified based on individual fusion construct, level, and material.

patients described in 15 studies (Table 2); allograft was used in 18 patients described in 5 studies (Table 4).

When nonrigid internal fixation was used for OCF, 179 (95\%) of 188 patients who received autograft fused, but neither of the 2 patients in whom allograft was used successfully fused (0\%) (Tables 2, 4, and 5). BMP was used in $48(26 \%)$ of 188 of autograft, nonrigid OCF constructs, resulting in a $100 \%$ fusion rate. BMP was not used in either of the allograft, nonrigid OCF constructs, neither of which fused.

When more rigid internal fixation was used (primary screw) for OCF, 134 (99\%) of 135 of patients fused with autograft and 17 (94\%) of 18 fused with allograft (Tables 2, 4, and 5). The use of BMP with screw constructs, with autograft or allograft, resulted in a $100 \%$ fusion rate; BMP was used in $30(22 \%)$ of 135 of the autologous, screw construct OCFs and in $13(72 \%)$ of 18 of the allograft, screw construct OCFs.

The majority of OCFs were occiput-C2 fusions, but there were a few patients who had longer constructs (Tables 2 and 4). For the OCF cohort, autologous bone was harvested most commonly from the IC, but a wide variety of donor sites were reported. Most allograft was morselized cancellous bone, but some surgeons used synthetic materials. Halo bracing was used in a majority of OCFs done with nonrigid internal fixation while it was used in a minority of patients who had rigid internal fixa- tion. The average follow-up was generally long, with an average range of 12 to 39 months in the various cohorts (Tables 2 and 4).

\section{PCF}

PCF (not including the occiput) performed with nonrigid fixation (primary wiring) was represented as follows: autologous bone was used in 154 patients in 17 studies (Table 3); allograft was used in 11 patients described in 6 studies (Table 4). PCF using rigid internal fixation (primary screw) was represented as follows: autologous bone was used in 62 patients described in 15 studies (Table 3); allograft was used in 34 patients described in 5 studies (Table 4).

When nonrigid internal fixation was used for PCF, $134(87 \%)$ of 154 patients who received autologous bone graft fused but only 4 (36\%) of 11 who received allograft successfully fused (Tables 3-5). Two patients underwent nonrigid PCF with BMP, one each in the autograft and allograft groups, both of whom fused.

When rigid internal fixation was used, 61 (98\%) of 62 fused with autologous bone graft and 31 (91\%) of 34 fused with allograft (Tables 3-5). BMP was not used in any of the patients with rigid $\mathrm{PCF}$ who received autologous bone graft. However, BMP was used in $85 \%$ of rigid PCF cases with allograft: 5 of $5(100 \%)$ cases that did not receive BMP fused; fusion was achieved in 26 (90\%) of 29 patients who did receive BMP. 


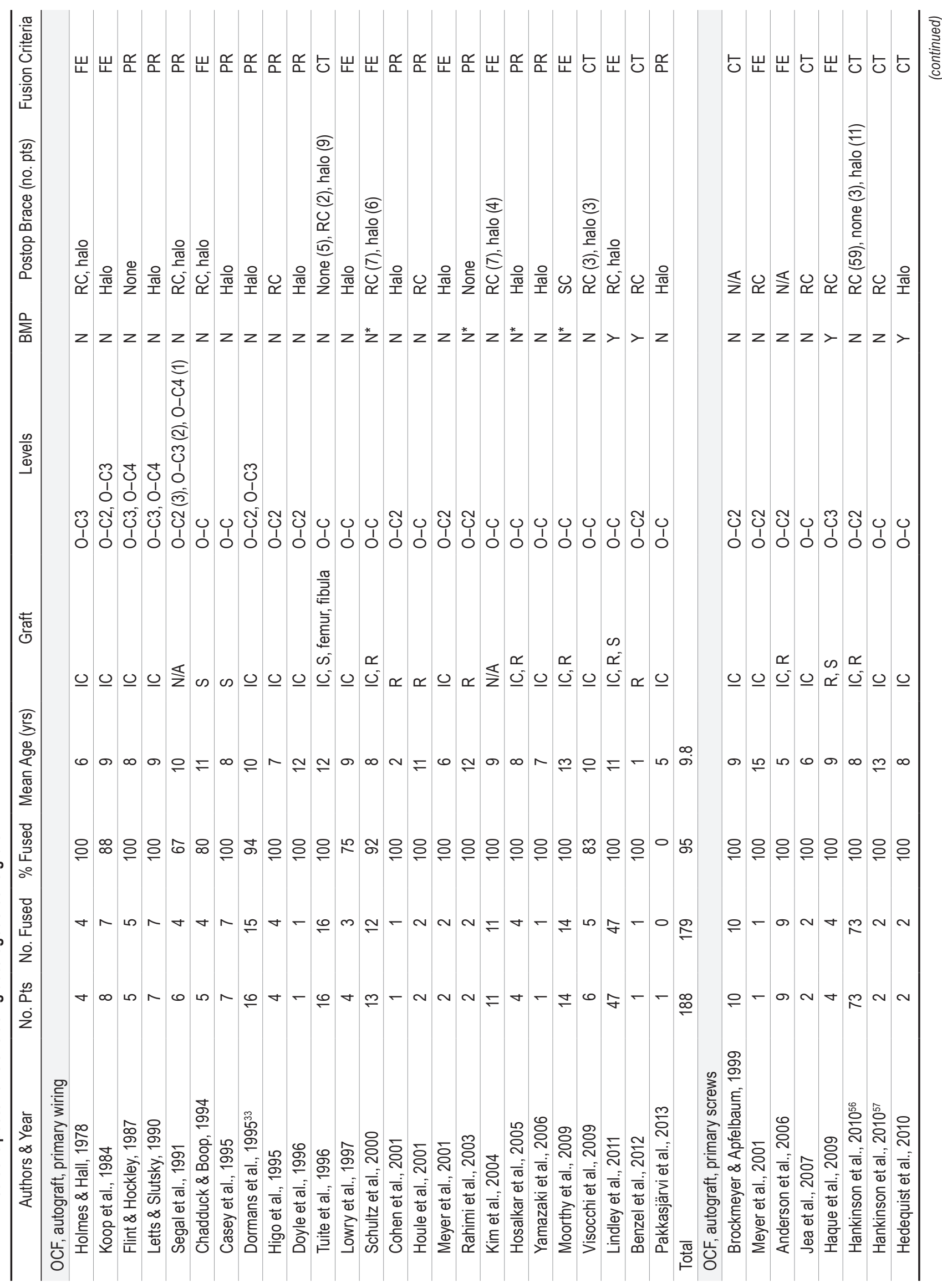




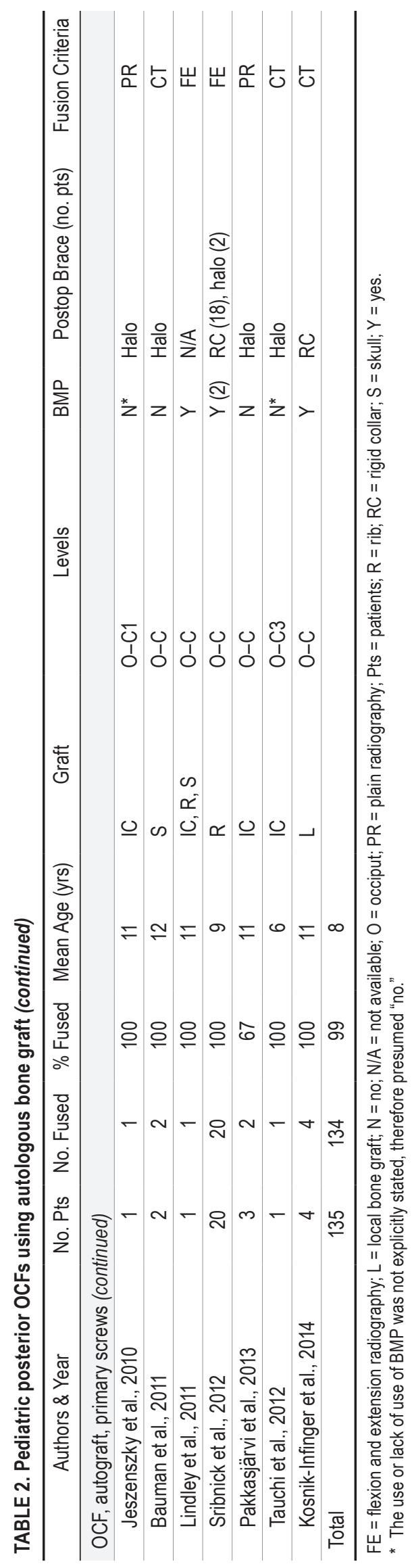

The vast majority of PCFs were $\mathrm{C} 1-2$ fusions, with a few patients undergoing fusion at lower cervical levels. Autologous bone grafts were generally structural grafts, harvested most commonly from the IC or ribs. Allograft used for PCF was often structural, but some authors used morselized cancellous chips or synthetic hydroxyapatite granules. Halo bracing was used in the majority of patients who underwent nonrigid internal fixation, but it was only used in 2 (2\%) of 96 patients who had rigid constructs. The average follow-up in each cohort was long, ranging from 15 to 73 months (Tables 3 and 4).

\section{Meta-Regression of the Entire Cohort}

Fusion outcomes were stratified across various factors of interest to identify potential predictors of successful fusion (Table 6). Univariate meta-regression analysis of the entire cohort showed that the following factors were positively associated with a successful fusion, with $\mathrm{p}$ values $<0.1$ : the use of autologous bone graft compared with allograft ( $p<0.001)$, OCF compared with PCF $(\mathrm{p}<0.001)$, rigid internal fixation compared with nonrigid fixation $(\mathrm{p}$ $=0.02$ ), fusion defined by CT compared with plain radiography ( $\mathrm{p}<0.001)$, and a shorter follow-up duration ( $\mathrm{p}$ $=0.07)$. Patient age, the use of BMP, and the method for bracing after surgery were not associated with successful fusion (Table 6 , middle columns).

The following factors were independently associated with successful fusion in multivariate analysis: the use of autologous bone graft compared with allograft (regression coefficient $=-0.13,95 \% \mathrm{CI}=-0.20$ to $-0.05, \mathrm{p}=0.001$ ), OCF compared with PCF (regression coefficient $=-0.07$, $95 \% \mathrm{CI}=-0.11$ to $-0.03, \mathrm{p}<0.001$ ), and fusion defined by CT compared with plain radiography (regression coefficient $=-0.10,95 \% \mathrm{CI}=-0.17$ to $-0.03, \mathrm{p}=0.005)$. The type of internal fixation and the duration of follow-up were correlated with fusion in the univariate analysis, but they had no correlation with fusion in the multivariate analysis (Table 6, columns on right).

\section{Meta-Regression of OCF Subset}

Subset analysis of only patients who underwent OCF showed similar trends as the overall cohort. Univariate analyses showed that patients who had fusion defined by CT were more likely to fuse than those who were assessed by plain radiography alone (regression coefficient $=-0.1,95 \% \mathrm{CI}=-0.17$ to $-0.04, \mathrm{p}=0.003)$. Patients who received allograft were less likely to achieve fusion (regression coefficient $=-0.1,95 \% \mathrm{CI}=-0.21$ to $-0.01, \mathrm{p}$ $=0.06$ ). Univariate analysis also showed that the type of internal fixation, use of BMP, method of bracing, age, and duration of follow-up were not associated with successful fusion ( $p>0.1)$.

Multivariate analysis, using factors with $\mathrm{p}<0.1$ in the univariate analysis, showed that patients studied only with plain radiography were less likely to achieve fusion (regression coefficient $=-0.11,95 \% \mathrm{CI}=-0.18$ to $-0.04, \mathrm{p}$ $=0.002$ ). Multivariate analysis of the OCF subset also showed that the use of allograft was also less likely to achieve successful fusion (regression coefficient $=-0.1$, $95 \% \mathrm{CI}=-0.21$ to $0.004, \mathrm{p}=0.06$ ), but the result was not statistically significant. 


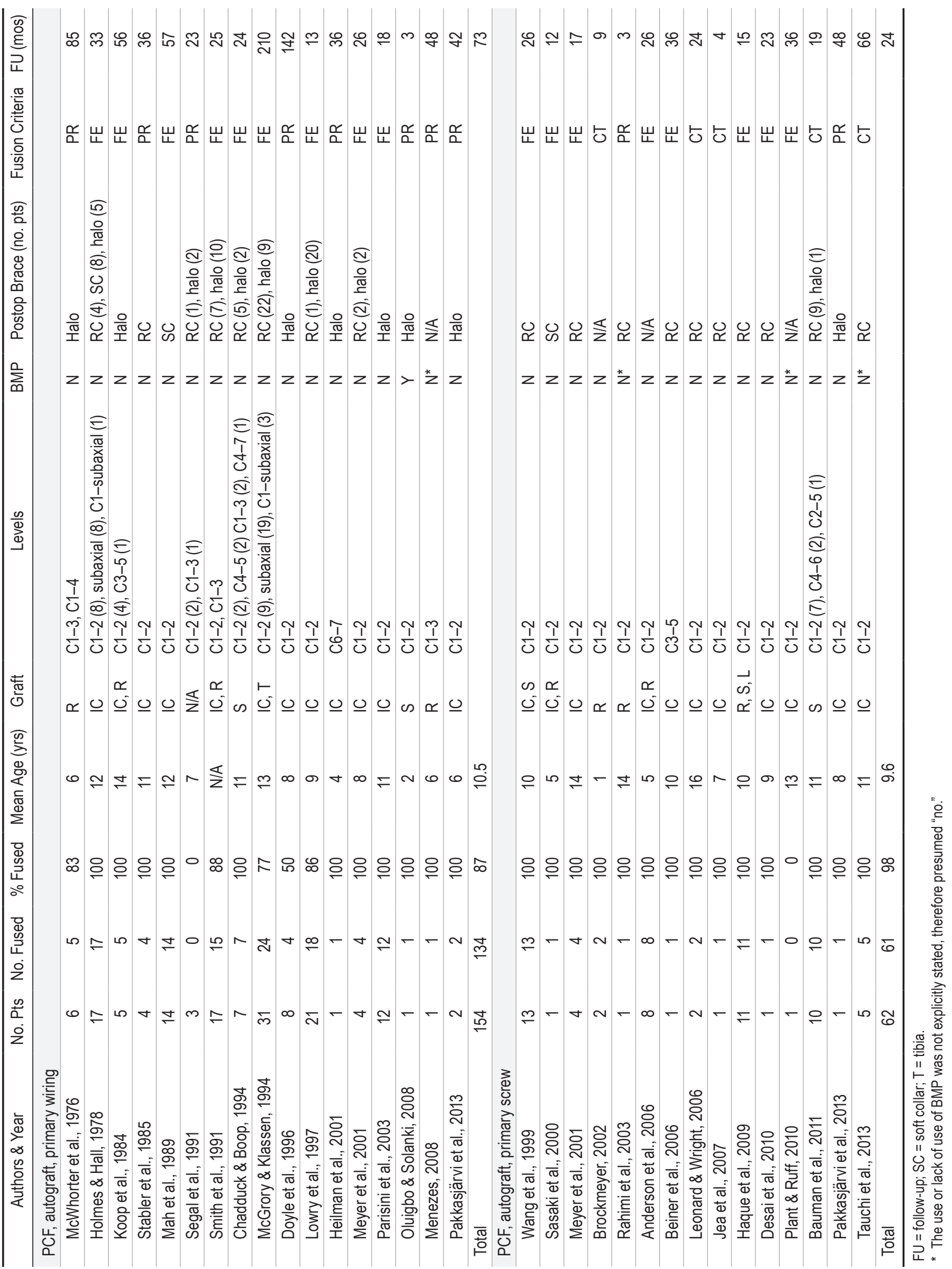




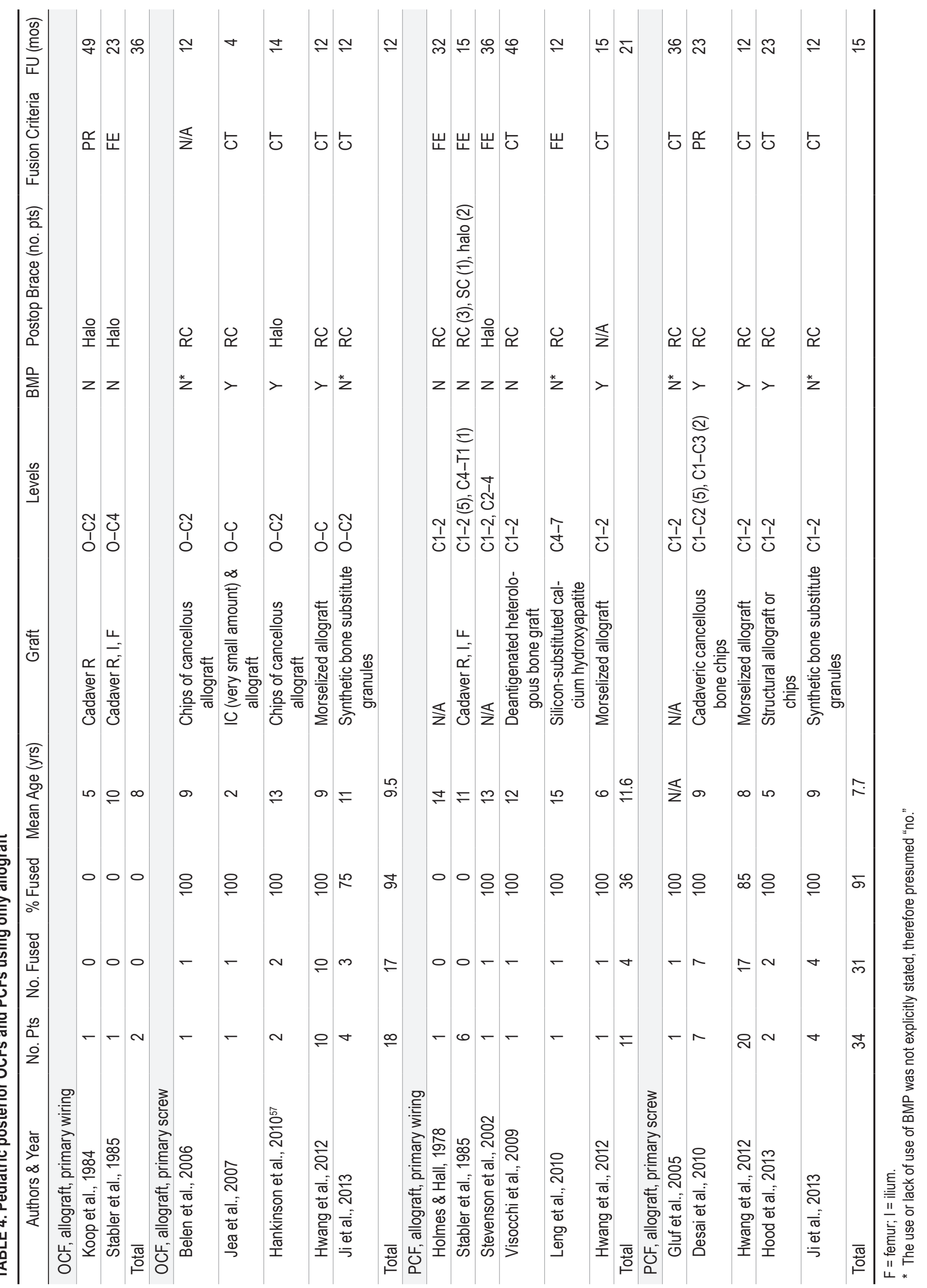




\section{Meta-Regression of PCF Subset}

Subset analysis of only patients who underwent PCF showed similar results to the OCF subset analysis; however, the effect of allograft use was more pronounced. The following factors were found to have a negative association with successful fusion $(\mathrm{p}<0.1)$ and were subsequently used in the multivariate analysis: use of allograft (regression coefficient $=-0.15,95 \% \mathrm{CI}=-0.25$ to $-0.05, \mathrm{p}=$ 0.002 ) and the use of plain radiography instead of CT or FE radiography to determine fusion (regression coefficient $=-0.14,95 \% \mathrm{CI}=-0.27$ to $-0.01, \mathrm{p}=0.04$ ). The type of internal fixation, use of BMP, type of bracing, age, and duration of follow-up were not correlated with successful fusion ( $\mathrm{p}>0.1)$.

Multivariate analysis, using the aforementioned factors with a $\mathrm{p}<0.1$ in the univariate analysis, showed similar findings: patients with allograft (regression coefficient $=$ $-0.15,95 \% \mathrm{CI}=-0.25$ to $-0.03, \mathrm{p}=0.01)$ and for whom plain radiography was used to define fusion (regression coefficient $=-0.16,95 \% \mathrm{CI}=-0.3$ to $-0.03, \mathrm{p}=0.02$ ) were less likely to experience a successful fusion.

\section{Publication Bias}

A funnel plot and Egger's test were used to assess the potential publication bias for all of the studies included in the review. The asymmetrical shape of the funnel plot (Fig. 2 ) and the result of the Egger's test for funnel plot asymmetry $(\mathrm{p}<0.001)$ suggest that publication bias may exist.

\section{Discussion}

\section{The Effect of the Levels Fused, Type of Bone Graft, and Method of Internal Fixation}

Our literature review confirms that fusion rates after OCF and PCF are high, except when fusion is performed using allograft and internal fixation that does not use screw constructs. The overall fusion rate for all OCF and PCF was $93 \%$, with OCF having a higher fusion rate than PCF (96\% vs 88\%). The overall fusion rate for all OCF and PCF was also higher in the patients who received autologous bone graft compared with those in whom allograft was used ( $94 \%$ vs $80 \%$ ). Similarly, fusion rates with autologous bone graft were higher than when allograft was used when comparative rates for OCF (97\% vs $85 \%)$ and PCF $(90 \%$ vs $78 \%$ ) were considered separately.

The use of rigid internal fixation also improved fusion rates, albeit to a lesser extent than the type of bone graft used: screw fixation was associated with higher fusion rates than nonrigid fixation in both OCF (99\% vs 94\%) and PCF (96\% vs $84 \%$ ). However, the most dramatic discrepancy in fusion rates was observed when comparing fusion rates when allograft was used in combination with nonrigid internal fixation: successful fusion was much higher when autograft was used with nonrigid fixation in both OCF $(95 \%$ vs $0 \%)$ and the PCF (87\% vs $36 \%)$. However, fusion rates when allograft was used in combination with rigid internal fixation were only slightly lower in both the OCF (99\% vs 94\%) and the PCF (98\% vs 91\%) subgroups. Similarly, our review for the entire cohort showed that higher fusion rates were associated with fusions done with autologous bone and in those that included the occiput.
TABLE 5. Summary of the literature review comparing overall fusion rates for OCF and PCF stratified by the type of internal fixation and the bone type*

\begin{tabular}{cccc}
\hline $\begin{array}{c}\text { Fusion } \\
\text { Type }\end{array}$ & Autograft & Allograft & $\begin{array}{c}\text { Combined } \\
\text { Autograft \& } \\
\text { Allograft }\end{array}$ \\
\hline OCF & & & \\
\hline Primary wiring & $179 / 188(95)$ & $0 / 2(0)$ & $179 / 190(94)$ \\
\hline Primary screw & $134 / 135(99)$ & $17 / 18(94)$ & $151 / 153(99)$ \\
\hline Total OCF & $313 / 323(97)$ & $17 / 20(85)$ & $330 / 343(96)$ \\
\hline PCF & & & \\
\hline Primary wiring & $134 / 154(87)$ & $4 / 11(36)$ & $138 / 165(84)$ \\
\hline Primary screw & $61 / 62(98)$ & $31 / 34(91)$ & $92 / 96(96)$ \\
\hline Total PCF & $195 / 216(90)$ & $35 / 45(78)$ & $230 / 261(88)$ \\
\hline Overall totals & $508 / 539(94)$ & $52 / 65(80)$ & $560 / 604(93)$ \\
\hline
\end{tabular}

* Values are presented as number/total patients (\%).

The findings of this review confirm that OCF and PCF in the pediatric population result in high overall fusion rates, particularly when screw-based internal fixation methods are used. Numerous studies have demonstrated the clear benefit of screw-based internal fixation techniques in adults and children, resulting in a significant reduction in the use of halo immobilization after surgery, and superior fusion rates compared with nonrigid internal fixation techniques..$^{5,17,43,62,73}$ Improved surgeon familiarity with internal fixation techniques, combined with advancements in imaging, surgical planning, and the ease of use of spinal instrumentation devices, have led to the widespread use and acceptance of screw-based internal fixation techniques in both adults and children.

While there is now little debate regarding the advantages of rigid internal fixation, there is no consensus on whether allogenic bone graft should be used alone as the fusion substrate, without harvesting autologous bone graft. ${ }^{67,69,73,93}$ The use of autograft has long been considered the "gold standard" for OCF and PCF in children, and its use continues to be advocated by many surgeons. . $^{1,50,58,67,150}$ As recently as 2005, authors have considered the use of onlay allograft to be inappropriate for $\mathrm{OCF}^{50}$ When viewed in the context of modern bone grafting techniques throughout the rest of the spine, where allograft and bone substitutes have been used with high fusion rates, reduced donor-site morbidity, and minimal complications, this preference for the use of autologous bone with OCF and PCF seems paradoxical. It is possible that this bias originated 30 years ago, based on surprisingly poor fusion rates in children with OCF and PCF who underwent allograft fusions, when the concept of bank bone use for spinal fusions started gaining traction. ${ }^{68,82,138}$

In 1984, Koop et al. noted that all of their pediatric OCF procedures performed with autologous bone resulted in fusion, whereas no fusion occurred in the 1 patient who received the allograft, leading the authors to recommend the use of autologous bone graft. ${ }^{82}$ A year later, Stabler et al. published an influential and frequently cited report of a $100 \%$ nonunion rate in 7 children who underwent PCF 
TABLE 6. Univariate and multivariate fixed-effects meta-regression analysis for the prevalence of pediatric patients who had a successful posterior OCF or subaxial PCF

\begin{tabular}{|c|c|c|c|c|c|c|c|c|}
\hline \multirow[b]{2}{*}{ Variable } & \multicolumn{4}{|c|}{ Univariate Analysis } & \multicolumn{4}{|c|}{ Multivariate Analysis } \\
\hline & Change in Prevalence & $\mathrm{LCL}$ & UCL & p Value & Change in Prevalence & $\mathrm{LCL}$ & UCL & p Value \\
\hline OCF & Ref & & & & & & & \\
\hline PCF & -0.1 & -0.13 & -0.06 & $<0.001$ & -0.07 & -0.11 & -0.03 & $<0.001$ \\
\hline \multicolumn{9}{|l|}{ Internal fixation method } \\
\hline Rods/screws & Ref & & & & Ref & & & \\
\hline Wire/cable/hook/onlay & -0.03 & -0.06 & -0.005 & 0.02 & -0.02 & -0.06 & 0.03 & 0.5 \\
\hline \multicolumn{9}{|l|}{ Bone source for fusion } \\
\hline Autograft & Ref & & & & Ref & & & \\
\hline Allograft & -0.16 & -0.23 & -0.09 & $<0.001$ & -0.13 & -0.2 & -0.05 & 0.001 \\
\hline \multicolumn{9}{|l|}{ BMP } \\
\hline $\mathrm{N}$ & Ref & & & & & & & \\
\hline $\mathrm{Y}$ & 0.02 & -0.01 & 0.06 & 0.13 & & & & \\
\hline $\mathrm{N}$ presumed & -0.04 & -0.1 & 0.03 & 0.26 & & & & \\
\hline \multicolumn{9}{|l|}{ Neck bracing after surgery } \\
\hline None & Ref & & & & & & & \\
\hline Rigid collar & 0.06 & -0.07 & 0.2 & 0.37 & & & & \\
\hline Soft collar & 0.05 & -0.1 & 0.2 & 0.51 & & & & \\
\hline Halo & -0.03 & -0.17 & 0.1 & 0.63 & & & & \\
\hline \multicolumn{9}{|l|}{ Criteria for fusion } \\
\hline CT & Ref & & & & Ref & & & \\
\hline FE & -0.03 & -0.05 & 0.003 & 0.08 & 0.01 & -0.04 & 0.05 & 0.8 \\
\hline PR & -0.14 & -0.2 & -0.08 & $<0.001$ & -0.1 & -0.17 & -0.03 & 0.005 \\
\hline Age & -0.001 & -0.007 & 0.005 & 0.75 & & & & \\
\hline FU duration & -0.0005 & -0.0009 & -0.00001 & 0.07 & -0.0002 & -0.0008 & 0.0004 & 0.57 \\
\hline
\end{tabular}

$\mathrm{LCL}=$ lower control limit; Ref = reference; $\mathrm{UCL}=$ upper control limit.

using cadaveric bone graft and wiring. ${ }^{138}$ Based on our review of the literature, 23 years passed before there was another published article regarding OCF using allograft in children following Koop's publication, and 17 years passed before another article described allograft use for PCF in children following Stabler's article. .11,82,138,140 $^{2}$

While there was a dearth of publications related to the use of allograft in pediatric cervical spine fusions for the 2 decades that followed the early failures reported in the 1980s, there has been a resurgence in interest over the most recent decade corresponding to the widespread use of rigid internal fixation techniques and the availability of BMP. ${ }^{56,69,73,78,88,151}$ Emboldened by the greater fusion rates associated with screw-based constructs, with or without the use of BMP, there has been a sharp rise in publications describing OCF and PCF in children and adults. Our review confirmed that fusion rates greater than $90 \%$ have been routinely reported with pediatric OCF and PCF when allograft is used with rigid internal fixation. This is in stark contrast to the very low fusion rates originally reported when less rigid internal fixation techniques were reported in the $1980 \mathrm{~s} .{ }^{68,82,138}$

We are unaware of any large pediatric series that directly compares fusion rates using autologous bone versus allograft for OCF or PCF. However, there is emerging evidence that similar fusion rates can be achieved using al- lograft in adult patients undergoing PCF. In a recently published meta-analysis of more than 1,000 adult patients who underwent a rod and screw posterior C1-2 fusion, Elliott et al. found that the fusion rate using allograft was very similar to that achieved with autograft (100\% vs $99.7 \%) .{ }^{40}$ Similarly, in a series that predominantly described PCF in adults with screw/rod constructs, Hood et al. reported a $100 \%$ fusion rate in 52 patients when BMP and allograft were combined. ${ }^{69}$ Similar fusion rates have been reported for OCF in adult patients using allograft as well. ${ }^{104}$ The findings of these large adult series confirm the trend seen in the pediatric literature: the use of allograft for OCF and PCF results in high fusion rates when combined with rigid internal fixation, with or without the use of BMP. ${ }^{39}$

\section{The Role of BMP in Allograft Fusions}

As described in the section above, surgeons caring for pediatric and adult patients are more frequently utilizing allograft during OCF and PCF, and they achieve high fusion rates when rigid internal fixation is used. ${ }^{39,73}$ While these results suggest that allograft bone may serve as an adequate fusion substrate in this surgical scenario, the frequent use of BMP with allograft confounds the argument that allograft alone is sufficient to result in fusion. Many reports of successful OCF and PCF with allograft in adults 


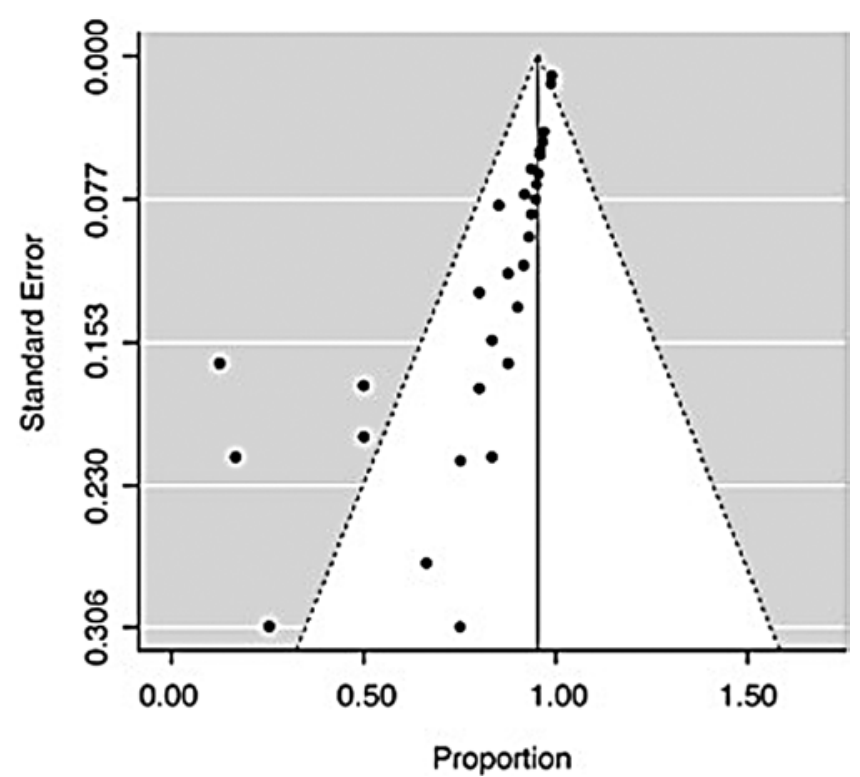

FIG. 2. Funnel plot of the Egger's test results showing an asymmetrical shape $(p<0.001)$ suggests that publication bias may exist.

also used BMP to promote fusion. ${ }^{39,69}$ Similarly, BMP was combined with allograft in the vast majority of OCF and PCF, resulting in successful fusion that we report in this review. Interestingly, the use of BMP was not statistically correlated with successful fusion in any of our univariate or multivariate analyses, when evaluating all OCF and PCF cases collectively or separately. However, the use of autograft was associated with a higher fusion rate than allograft in most of our analyses. These findings beg the question as to the necessity of BMP when allograft is used in conjunction with rigid internal fixation. While it is comforting to the surgeon to supplement allograft fusion with BMP, a substance that provides the osteoinductive properties that allograft is missing, is it necessary?

Questions regarding the necessity of BMP are not trivial considering the apprehensions that have been raised about the short- and long-term risks of utilizing BMP. In fact, the FDA recently issued a warning against the routine use of BMP in patients under 18 years, because its safety and effectiveness have not been reviewed or approved in this population. ${ }^{149}$ Clearly, while multiple reports have shown that BMP can enhance spinal fusion rates, its use comes at a price. ${ }^{19,42}$ While an extensive recent administrative database review of short-term complications in pediatric spinal fusions failed to demonstrate a higher complication rate when BMP was used, the authors emphasize that caution should be used in interpreting this data based on the duration of follow-up and the limitations of their study. ${ }^{119}$ BMP is expensive, and its use has been associated with swelling, seroma formation, hematoma, ectopic bone formation, osteomyelitis and bone resorption, dysphagia, and breathing difficulties..$^{20,91,93,130,132,136}$ Our analysis suggests that rigid internal fixation techniques may play a more important role than BMP in promoting fusion when allograft is used; however, our conclusions are limited by the small sample sizes reported and the limitations inherent in a retrospective review of the literature.

\section{Other Variables Studied Predicting Successful OCF and PCF}

Our analyses consistently showed that the assessment of fusion with static cervical plain radiography and shorter follow-up were associated with a lower fusion rate. We believe this association can be explained by the very nature of patient assessments after surgery and the era during which the studies were performed. While CT and FE radiography are now considered the optimal methods by which to assess fusion, CT was not available for patient assessment in early reports, when fusion rates were lower. Also, if static radiographs fail to demonstrate fusion, it is unlikely that clinicians would subsequently order dynamic studies, for fear of causing neurological compromise when the neck is manipulated. Lower fusion rates with longer follow-up can be accounted for by the fact that patients who experience failure to fuse often go on to other procedures, thereby extending their follow-up after the index operation.

Patient age also did not correlate with fusion rates in any of the analyses, a finding that is not surprising in pediatric patients, who generally exhibit a strong propensity to fuse. Based on the knowledge that rigid internal fixation improves fusion rates, it is possible that a larger study involving infants in whom rigid internal fixation is not possible might produce lower fusion rates. There was scant information pertaining to very young children reported in any of the papers we reviewed for this analysis.

The method of bracing after surgery also did not correlate with fusion rates. Halo immobilization was much more frequently used when nonrigid internal fixation was performed, but fusion rates were still relatively high. The majority of patients who underwent rigid internal fixation used a cervical collar or no external bracing at all after surgery.

\section{Study Limitations}

This study has all the major limitations of a retrospective literature review and, as a result, is subject to the inherent shortcomings of such manuscripts. All conclusions from this review are based on Class III data. We could not independently assess the quality of the surgical technique, the completeness of the follow-up, or the overall quality of the individual studies. The description of the operative technique in each article was often limited, particularly in regard to the precise fusion technique performed and whether BMP was used. Eighty-eight papers were eliminated from the review because they did not meet the inclusion criteria, but the description of the operative details was often scant in some of the articles that were included in the analysis. Judgments were made about whether a fusion was an allograft or autograft based on the written description in the manuscript. Also, judgments were made about whether a fusion was successful based on radiographic criteria. In many of the earlier manuscripts, CT was not available to identify fusion. Even in more recent studies, CT was not routinely used to assess fusion mass, even though CT is considered by many to be the standard imaging modality to define fusion.

Many of the studies in our review have a heterogeneous population and treated a wide variety of pathologies, which 
we did not include in our analysis because the documentation was inconsistent. Additionally, inconsistent documentation of several of our other study variables inevitably skews our results and interpretation. It is also possible that authors are more likely to report successful fusions rather than failed fusion in the literature. Lastly, authors who had produced multiple studies could potentially report a single patient in several manuscripts, which leads to repetition of data.

Finally, it would have been ideal to subdivide the patients into 3 homogenous groups (OCF, $\mathrm{C} 1-2$ fusion, and subaxial PCF), because we suspect that $\mathrm{C} 1-2$ fusion rates would have been higher than subaxial fusion rates. However, many important papers from 30 to 40 years ago, when longer constructs were more common, failed to separate the results so precisely. We suggest that future studies on this topic further stratify the data to separate subaxial PCF from pure $\mathrm{C} 1-2$ fusions.

\section{Conclusions}

OCF and PCF result in high overall fusion rates in pediatric patients, regardless of whether autologous bone or allograft are used as the fusion substrate. Initial enthusiasm for allograft fusion 30 years ago, before more rigid internal fixation methods were developed, was dampened by very poor fusion rates when allograft was used without autologous bone grafting. More modern rigid internal fixation techniques have resulted in high fusion rates and a substantial reduction in the use of halo orthosis after surgery. Our meta-regression of published data over the past 50 years shows that fusion rates were higher with OCF than PCF and that autologous bone was more likely to lead to successful fusion than allograft. However, studies published in the past decade show that high fusion rates can be expected when rigid internal fixation is combined with the use of allograft, while eliminating donor-site morbidity associated with harvesting autologous bone graft. These impressively high fusion rates achieved with allograft in pediatric patients are similar to results reported in adults. While previous studies have suggested that such admirable fusion rates are related to improved internal fixation techniques, most patients also had their allograft fusions augmented with BMP. This review suggests that allograft fusion can produce high fusion rates in pediatric patients undergoing OCF or PCF with rigid internal fixation, but the importance of the role BMP plays in fusion is undetermined.

\section{References}

1. Ahmed R, Traynelis VC, Menezes AH: Fusions at the craniovertebral junction. Childs Nerv Syst 24:1209-1224, 2008

2. Ain MC, Chaichana KL, Schkrohowsky JG: Retrospective study of cervical arthrodesis in patients with various types of skeletal dysplasia. Spine (Phila Pa 1976) 31:E169E174, 2006

3. Anakwenze OA, Auerbach JD, Buck DW, Garg S, Simon SL, Sutton LN, et al: The role of concurrent fusion to prevent spinal deformity after intramedullary spinal cord tumor excision in children. J Pediatr Orthop 31:475-479, 2011

4. Anderson RC, Kan P, Gluf WM, Brockmeyer DL: Longterm maintenance of cervical alignment after occipitocer- vical and atlantoaxial screw fixation in young children. $\mathbf{J}$ Neurosurg 105 (1 Suppl):55-61, 2006

5. Anderson RC, Ragel BT, Mocco J, Bohman LE, Brockmeyer DL: Selection of a rigid internal fixation construct for stabilization at the craniovertebral junction in pediatric patients. J Neurosurg 107 (1 Suppl):36-42, 2007

6. Arkader A, Hosalkar HS, Drummond DS, Dormans JP: Analysis of halo-orthoses application in children less than three years old. J Child Orthop 1:337-344, 2007

7. Aryan HE, Newman CB, Nottmeier EW, Acosta FL Jr, Wang VY, Ames CP: Stabilization of the atlantoaxial complex via $\mathrm{C}-1$ lateral mass and $\mathrm{C}-2$ pedicle screw fixation in a multicenter clinical experience in 102 patients: modification of the Harms and Goel techniques. J Neurosurg Spine 8:222-229, 2008

8. Bailey RW: Fractures and dislocations of the cervical spine-diagnosis and treatment. Curr Pract Orthop Surg 4:132-166, 1969

9. Bauman JA, Hardesty DA, Heuer GG, Storm PB: Use of occipital bone graft in pediatric posterior cervical fusion: an alternative paramedian technique and review of the literature. J Neurosurg Pediatr 7:475-481, 2011

10. Beiner JM, Sastry A, Berchuck M, Grauer JN, Kwon BK, Ratliff JK, et al: An aneurysmal bone cyst in the cervical spine of a 10-year-old girl: a case report. Spine (Phila Pa 1976) 31:E475-E479, 2006

11. Belen D, Simsek S, Yigitkanli K, Bavbek M: Internal reduction established by occiput-C2 pedicle polyaxial screw stabilization in pediatric atlantoaxial rotatory fixation. Pediatr Neurosurg 42:328-332, 2006

12. Benzel EC, Zhang DH, Iannotti C, Refai D, Ruggieri P, Krishnaney A: Occipitocervical fusion in an infant with atlantooccipital dislocation. World Neurosurg 78:715. e17-715.e24, 2012

13. Bisson E, Schiffern A, Daubs MD, Brodke DS, Patel AA: Combined occipital-cervical and atlantoaxial disassociation without neurologic injury: case report and review of the literature. Spine (Phila Pa 1976) 35:E316-E321, 2010

14. Bollo RJ, Riva-Cambrin J, Brockmeyer MM, Brockmeyer DL: Complex Chiari malformations in children: an analysis of preoperative risk factors for occipitocervical fusion. $\mathbf{J}$ Neurosurg Pediatr 10:134-141, 2012

15. Brockmeyer D, Apfelbaum R, Tippets R, Walker M, Carey L: Pediatric cervical spine instrumentation using screw fixation. Pediatr Neurosurg 22:147-157, 1995

16. Brockmeyer DL: A bone and cable girth-hitch technique for atlantoaxial fusion in pediatric patients. Technical note. J Neurosurg 97 (3 Suppl):400-402, 2002

17. Brockmeyer DL, Apfelbaum RI: A new occipitocervical fusion construct in pediatric patients with occipitocervical instability. Technical note. J Neurosurg 90 (2 Suppl):271275, 1999

18. Buttermann GR, Glazer PA, Bradford DS: The use of bone allografts in the spine. Clin Orthop Relat Res (324):75-85, 1996

19. Carlisle E, Fischgrund JS: Bone morphogenetic proteins for spinal fusion. Spine J 5 (6 Suppl):240S-249S, 2005

20. Carragee EJ, Bono CM, Scuderi GJ: Pseudomorbidity in iliac crest bone graft harvesting: the rise of rhBMP-2 in short-segment posterior lumbar fusion. Spine J 9:873-879, 2009

21. Casey AT, Hayward RD, Harkness WF, Crockard HA: The use of autologous skull bone grafts for posterior fusion of the upper cervical spine in children. Spine (Phila Pa 1976) 20:2217-2220, 1995

22. Chadduck WM, Boop FA: Use of full-thickness calvarial bone grafts for cervical spinal fusions in pediatric patients. Pediatr Neurosurg 20:107-112, 1994

23. Chamoun RB, Relyea KM, Johnson KK, Whitehead 
WE, Curry DJ, Luerssen TG, et al: Use of axial and subaxial translaminar screw fixation in the management of upper cervical spinal instability in a series of 7 children. Neurosurgery 64:734-739, 2009

24. Chen JF, Wu CT, Lee SC, Lee ST: Posterior atlantoaxial transpedicular screw and plate fixation. Technical note. J Neurosurg Spine 2:386-392, 2005

25. Cohen MW, Drummond DS, Flynn JM, Pill SG, Dormans JP: A technique of occipitocervical arthrodesis in children using autologous rib grafts. Spine (Phila Pa 1976) 26:825829,2001

26. Couture D, Avery N, Brockmeyer DL: Occipitocervical instrumentation in the pediatric population using a custom loop construct: initial results and long-term follow-up experience. J Neurosurg Pediatr 5:285-291, 2010

27. Crostelli M, Mariani M, Mazza O, Ascani E: Cervical fixation in the pediatric patient: our experience. Eur Spine J 18 (Suppl 1):20-28, 2009

28. Dede O, Thacker MM, Rogers KJ, Oto M, Belthur MV, Baratela W, et al: Upper cervical fusion in children with Morquio syndrome: intermediate to long-term results. J Bone Joint Surg Am 95:1228-1234, 2013

29. Desai R, Stevenson CB, Crawford AH, Durrani AA, Mangano FT: C-1 lateral mass screw fixation in children with atlantoaxial instability: case series and technical report. J Spinal Disord Tech 23:474-479, 2010

30. Deutsch H, Haid R, Rodts G Jr, Mummaneni PV: The decision-making process: allograft versus autograft. Neurosurgery 60 (1 Supp1 1):S98-S102, 2007

31. Dickerman RD, Morgan JT, Mittler M: Circumferential cervical spine surgery in an 18-month-old female with traumatic disruption of the odontoid and C3 vertebrae. Case report and review of techniques. Case report and review of techniques. Pediatr Neurosurg 41:88-92, 2005

32. Dormans JP, Criscitiello AA, Drummond DS, Davidson RS: Complications in children managed with immobilization in a halo vest. J Bone Joint Surg Am 77:1370-1373, 1995

33. Dormans JP, Drummond DS, Sutton LN, Ecker ML, Kopacz KJ: Occipitocervical arthrodesis in children. A new technique and analysis of results. J Bone Joint Surg Am 77:1234-1240, 1995

34. Doyle JS, Lauerman WC, Wood KB, Krause DR: Complications and long-term outcome of upper cervical spine arthrodesis in patients with Down syndrome. Spine (Phila Pa 1976) 21:1223-1231, 1996

35. Duhem R, Tonnelle V, Vinchon M, Assaker R, Dhellemmes P: Unstable upper pediatric cervical spine injuries: report of 28 cases and review of the literature. Childs Nerv Syst 24:343-348, 2008

36. Dzenitis AJ: Spontaneous atlanto-axial dislocation in a mongoloid child with spinal cord compression. Case report. J Neurosurg 25:458-460, 1966

37. Eleraky MA, Theodore N, Adams M, Rekate HL, Sonntag VK: Pediatric cervical spine injuries: report of 102 cases and review of the literature. J Neurosurg 92 (1 Suppl): 12 17,2000

38. Elliott RE, Kang MM, Smith ML, Frempong-Boadu A: C2 nerve root sectioning in posterior atlantoaxial instrumented fusions: a structured review of literature. World Neurosurg 78:697-708, 2012

39. Elliott RE, Morsi A, Frempong-Boadu A, Smith ML: Is allograft sufficient for posterior atlantoaxial instrumented fusions with screw and rod constructs? A structured review of literature. World Neurosurg 78:326-338, 2012

40. Elliott RE, Tanweer O, Boah A, Morsi A, Ma T, FrempongBoadu A, et al: Outcome comparison of atlantoaxial fusion with transarticular screws and screw-rod constructs: metaanalysis and review of literature. J Spinal Disord Tech 27:11-28, 2014
41. Elliott RE, Tanweer O, Boah A, Morsi A, Ma T, Smith ML, et al: Atlantoaxial fusion with screw-rod constructs: meta-analysis and review of literature. World Neurosurg 81:411-421, 2014

42. Fahim DK, Whitehead WE, Curry DJ, Dauser RC, Luerssen TG, Jea A: Routine use of recombinant human bone morphogenetic protein-2 in posterior fusions of the pediatric spine: safety profile and efficacy in the early postoperative period. Neurosurgery 67:1195-1204, 2010

43. Fargen KM, Anderson RC, Harter DH, Angevine PD, Coon VC, Brockmeyer DL, et al: Occipitocervicothoracic stabilization in pediatric patients. J Neurosurg Pediatr 8:57-62, 2011

44. Fenoy AJ, Menezes AH, Fenoy KA: Craniocervical junction fusions in patients with hindbrain herniation and syringohydromyelia. J Neurosurg Spine 9:1-9, 2008

45. Fielding JW, Hawkins RJ, Ratzan SA: Spine fusion for atlanto-axial instability. J Bone Joint Surg Am 58:400407, 1976

46. Fielding JW, Hensinger RN: Cervical spine surgery: past, present, and future potential. Orthopedics 10:1701-1705, 1987

47. Flint GA, Hockley AD: Internal fixation for atlanto-axial instability in children. Childs Nerv Syst 3:368-370, 1987

48. Fuchs PD, Bertrand S, Iwinski H, Pellet J: Traumatic C6-C7 dislocation in a 14 year old with posterior spinal fusion for idiopathic scoliosis. J Trauma 51:1004-1007, 2001

49. Garg S, Hosalkar H, Dormans JP: Quadriplegia in a 10 year-old boy due to multiple cervical neurofibromas. Spine (Phila Pa 1976) 28:E339-E343, 2003

50. Gluf WM, Brockmeyer DL: Atlantoaxial transarticular screw fixation: a review of surgical indications, fusion rate, complications, and lessons learned in 67 pediatric patients. J Neurosurg Spine 2:164-169, 2005

51. Goel A: Bioglue and allograft versus autograft for craniovertebral instrumented fusion. World Neurosurg 82:10501051,2013

52. Govender S, Parbhoo AH, Kumar KP: Tuberculosis of the cervicodorsal junction. J Pediatr Orthop 21:285-287, 2001

53. Griswold DM, Albright JA, Schiffman E, Johnson R, Southwick W: Atlanto-axial fusion for instability. J Bone Joint Surg Am 60:285-292, 1978

54. Hamblen DL: Occipito-cervical fusion. Indications, technique and results. J Bone Joint Surg Br 49:33-45, 1967

55. Hamilton DK, Smith JS, Reames DL, Williams BJ, Chernavvsky DR, Shaffrey CI: Safety, efficacy, and dosing of recombinant human bone morphogenetic protein-2 for posterior cervical and cervicothoracic instrumented fusion with a minimum 2-year follow-up. Neurosurgery 69:103111,2011

56. Hankinson TC, Avellino AM, Harter D, Jea A, Lew S, Pincus D, et al: Equivalence of fusion rates after rigid internal fixation of the occiput to C-2 with or without C-1 instrumentation. J Neurosurg Pediatr 5:380-384, 2010

57. Hankinson TC, Grunstein E, Gardner P, Spinks TJ, Anderson RC: Transnasal odontoid resection followed by posterior decompression and occipitocervical fusion in children with Chiari malformation Type I and ventral brainstem compression. J Neurosurg Pediatr 5:549-553, 2010

58. Haque A, Price AV, Sklar FH, Swift DM, Weprin BE, Sacco DJ: Screw fixation of the upper cervical spine in the pediatric population. Clinical article. J Neurosurg Pediatr 3:529-533, 2009

59. Hardy JR, Pouliquen JC, Pennecot GF: [Posterior arthrodeses of the upper cervical spine in children and adolescents. Apropos of 19 cases.] Rev Chir Orthop Repar Appar Mot 71:153-166, 1985 (Fr)

60. Harrington JF Jr, Park MC: Single level arthrodesis as treat- 
ment for midcervical fracture subluxation: a cohort study. $\mathbf{J}$ Spinal Disord Tech 20:42-48, 2007

61. Hedequist D, Bekelis K, Emans J, Proctor MR: Single stage reduction and stabilization of basilar invagination after failed prior fusion surgery in children with Down's syndrome. Spine (Phila Pa 1976) 35:E128-E133, 2010

62. Hedequist D, Hresko T, Proctor M: Modern cervical spine instrumentation in children. Spine (Phila Pa 1976) 33:379383, 2008

63. Heilman CB, Riesenburger RI: Simultaneous noncontiguous cervical spine injuries in a pediatric patient: case report. Neurosurgery 49:1017-1021, 2001

64. Heuer GG, Hardesty DA, Bhowmick DA, Bailey R, Magge SN, Storm PB: Treatment of pediatric atlantoaxial instability with traditional and modified Goel-Harms fusion constructs. Eur Spine J 18:884-892, 2009

65. Higgins JP, Thompson SG: Quantifying heterogeneity in a meta-analysis. Stat Med 21:1539-1558, 2002

66. Higo M, Sakou T, Taketomi E, Kojyo T: Occipitocervical fusion by Luque loop rod instrumentation in Down syndrome. J Pediatr Orthop 15:539-542, 1995

67. Hillard VH, Fassett DR, Finn MA, Apfelbaum RI: Use of allograft bone for posterior C1-2 fusion. J Neurosurg Spine 11:396-401, 2009

68. Holmes JC, Hall JE: Fusion for instability and potential instability of the cervical spine in children and adolescents. Orthop Clin North Am 9:923-943, 1978

69. Hood B, Hamilton DK, Smith JS, Dididze M, Shaffrey C, Levi AD: The use of allograft and recombinant human bone morphogenetic protein for instrumented atlantoaxial fusions. World Neurosurg 82:1369-1373, 2013

70. Hooley E, Chaput CD, Rahm M: Internal fixation without fusion of a flexion-distraction injury in the lower cervical spine of a three-year-old. Spine J 6:50-54, 2006

71. Hosalkar HS, Cain EL, Horn D, Chin KR, Dormans JP, Drummond DS: Traumatic atlanto-occipital dislocation in children. J Bone Joint Surg Am 87:2480-2488, 2005

72. Houle P, McDonnell DE, Vender J: Traumatic atlantooccipital dislocation in children. Pediatr Neurosurg 34:193-197, 2001

73. Hwang SW, Gressot LV, Chern JJ, Relyea K, Jea A: Complications of occipital screw placement for occipitocervical fusion in children. J Neurosurg Pediatr 9:586-593, 2012

74. Jackson RJ, Gokaslan ZL: Occipitocervicothoracic fixation for spinal instability in patients with neoplastic processes. J Neurosurg 91 (1 Suppl):81-89, 1999

75. Jandali S, Diluna ML, Storm PB, Low DW: Use of the vascularized free fibula graft with an arteriovenous loop for fusion of cervical and thoracic spinal defects in previously irradiated pediatric patients. Plast Reconstr Surg 127:1932-1938, 2011

76. Jea A, Taylor MD, Dirks PB, Kulkarni AV, Rutka JT, Drake JM: Incorporation of C-1 lateral mass screws in occipitocervical and atlantoaxial fusions for children 8 years of age or younger. Technical note. J Neurosurg 107 (2 Suppl):178-183, 2007

77. Jeszenszky D, Fekete TF, Lattig F, Bognár L: Intraarticular atlantooccipital fusion for the treatment of traumatic occipitocervical dislocation in a child: a new technique for selective stabilization with nine years follow-up. Spine (Phila Pa 1976) 35:E421-E426, 2010

78. Ji XT, Li A, Wang Q, Zhao DS, Huang G, Liu WP, et al: Posterior reduction and instrumentation with rod-screw construct for atlanto-axial dislocation: a single institutional study with 21 consecutive cases. Clin Neurol Neurosurg 115:1433-1439, 2013

79. Kalra SK, Jain VK, Jaiswal AK, Behari S: Occipitocervical contoured rod stabilization: does it still have a role amidst the modern stabilization techniques? Neurol India 55:363368,2007

80. Kang MM, Anderer EG, Elliott RE, Kalhorn SP, FrempongBoadu A: C2 nerve root sectioning in posterior C1-2 instrumented fusions. World Neurosurg 78:170-177, 2012

81. Kim LJ, Rekate HL, Klopfenstein JD, Sonntag VK: Treatment of basilar invagination associated with Chiari I malformations in the pediatric population: cervical reduction and posterior occipitocervical fusion. J Neurosurg 101 (2 Suppl):189-195, 2004

82. Koop SE, Winter RB, Lonstein JE: The surgical treatment of instability of the upper part of the cervical spine in children and adolescents. J Bone Joint Surg Am 66:403-411, 1984

83. Kosnik-Infinger L, Glazier SS, Frankel BM: Occipital condyle to cervical spine fixation in the pediatric population. J Neurosurg Pediatr 13:45-53, 2014

84. Lee MJ, Dettori JR, Standaert CJ, Ely CG, Chapman JR: Indication for spinal fusion and the risk of adjacent segment pathology: does reason for fusion affect risk? A systematic review. Spine (Phila Pa 1976) 37 (22 Suppl):S40-S51, 2012

85. Lee TT, Manzano GR, Green BA: Modified open-door cervical expansive laminoplasty for spondylotic myelopathy: operative technique, outcome, and predictors for gait improvement. J Neurosurg 86:64-68, 1997

86. Lekovic GP, Mariwalla NR, Horn EM, Chang S, Rekate HL, Theodore N: Skeletal dysplasia involving the subaxial cervical spine. Report of two cases and review of the literature. Neurosurg Focus 20(2):E8, 2006

87. Lementowski PW, Lucas P, Taddonio RF: Acute and chronic complications of intracortical iliac crest bone grafting versus the traditional corticocancellous technique for spinal fusion surgery. Orthopedics 33:33, 2010

88. Leng LZ, Shajari M, Härtl R: Management of acute cervical compression fractures in two patients with osteogenesis imperfecta. Spine (Phila Pa 1976) 35:E1248-E1252, 2010

89. Leonard JR, Wright NM: Pediatric atlantoaxial fixation with bilateral, crossing C-2 translaminar screws. Technical note. J Neurosurg 104 (1 Suppl):59-63, 2006

90. Letts M, Slutsky D: Occipitocervical arthrodesis in children. J Bone Joint Surg Am 72:1166-1170, 1990

91. Lindley TE, Dahdaleh NS, Menezes AH, Abode-Iyamah KO: Complications associated with recombinant human bone morphogenetic protein use in pediatric craniocervical arthrodesis. J Neurosurg Pediatr 7:468-474, 2011

92. Lowry DW, Pollack IF, Clyde B, Albright AL, Adelson PD: Upper cervical spine fusion in the pediatric population. $\mathbf{J}$ Neurosurg 87:671-676, 1997

93. Lubelski D, Benzel EC: C1-C2 Fusion: Promoting stability, reducing morbidity. World Neurosurg 82:1052-1054, 2014

94. Mah JY, Thometz J, Emans J, Millis M, Hall JE: Threaded $\mathrm{K}$-wire spinous process fixation of the axis for modified Gallie fusion in children and adolescents. J Pediatr Orthop 9:675-679, 1989

95. Martus JE, Griffith TE, Dear JC, Rathjen KE: Pediatric cervical kyphosis: a comparison of arthrodesis techniques. Spine (Phila Pa 1976) 36:E1145-E1 153, 2011

96. McGrory BJ, Klassen RA: Arthrodesis of the cervical spine for fractures and dislocations in children and adolescents. A long-term follow-up study. J Bone Joint Surg Am 76:1606-1616, 1994

97. McWhorter JM, Alexander E, Davis CH, Kelly L: Posterior cervical fusion in children. J Neurosurg 45:211-215, 1976

98. Menezes AH: Craniovertebral junction neoplasms in the pediatric population. Childs Nerv Syst 24:1173-1186, 2008

99. Meyer B, Vieweg U, Rao JG, Stoffel M, Schramm J: Surgery for upper cervical spine instabilities in children. Acta Neurochir (Wien) 143:759-766, 2001 
100. Moorthy RK, Rajshekhar V: Changes in cervical spine curvature in pediatric patients following occipitocervical fusion. Childs Nerv Syst 25:961-967, 2009

101. Mummaneni PV, Lu DC, Dhall SS, Mummaneni VP, Chou D: C1 lateral mass fixation: a comparison of constructs. Neurosurgery 66 (3 Suppl): 153-160, 2010

102. Nakagawa T, Yone K, Sakou T, Yanase M: Occipitocervical fusion with C1 laminectomy in children. Spine (Phila Pa 1976) 22:1209-1214, 1997

103. Ni B, Zhou F, Guo Q, Li S, Guo X, Xie N: Modified technique for C1-2 screw-rod fixation and fusion using autogenous bicortical iliac crest graft. Eur Spine J 21:156-164, 2012

104. Nockels RP, Shaffrey CI, Kanter AS, Azeem S, York JE: Occipitocervical fusion with rigid internal fixation: longterm follow-up data in 69 patients. J Neurosurg Spine 7:117-123, 2007

105. Oluigbo CO, Solanki GA: Use of recombinant human bone morphogenetic protein- 2 to enhance posterior cervical spine fusion at 2 years of age: technical note. Pediatr Neurosurg 44:393-396, 2008

106. Pakkasjärvi N, Mattila M, Remes V, Helenius I: Upper cervical spine fusion in children with skeletal dysplasia. Scand J Surg 102:189-196, 2013

107. Pang D: Atlantoaxial rotatory fixation. Neurosurgery 66 (3 Suppl):161-183, 2010

108. Pang D, Li V: Atlantoaxial rotatory fixation: part 3-a prospective study of the clinical manifestation, diagnosis, management, and outcome of children with alantoaxial rotatory fixation. Neurosurgery 57:954-972, 2005

109. Pang D, Nemzek WR, Zovickian J: Atlanto-occipital dislocation-part 2: The clinical use of (occipital) condyle-C1 interval, comparison with other diagnostic methods, and the manifestation, management, and outcome of atlanto-occipital dislocation in children. Neurosurgery 61:995-1015, 2007

110. Parisini P, Di Silvestre M, Greggi T, Bianchi G: C1-C2 posterior fusion in growing patients: long-term follow-up. Spine (Phila Pa 1976) 28:566-572, 2003

111. Parker SL, McGirt MJ, Garcés-Ambrossi GL, Mehta VA, Sciubba DM, Witham TF, et al: Translaminar versus pedicle screw fixation of $\mathrm{C} 2$ : comparison of surgical morbidity and accuracy of 313 consecutive screws. Neurosurgery 64 (5 Suppl 2):343-349, 2009

112. Peng X, Chen L, Wan Y, Zou X: Treatment of primary basilar invagination by cervical traction and posterior instrumented reduction together with occipitocervical fusion. Spine (Phila Pa 1976) 36:1528-1531, 2011

113. Plant JG, Ruff SJ: Migration of rod through skull, into brain following C1-C2 instrumental fusion for os odontoideum: a case report. Spine (Phila Pa 1976) 35:E90-E92, 2010

114. Price CT, Connolly JF, Carantzas AC, Ilyas I: Comparison of bone grafts for posterior spinal fusion in adolescent idiopathic scoliosis. Spine (Phila Pa 1976) 28:793-798, 2003

115. Rahimi SY, Stevens EA, Yeh DJ, Flannery AM, Choudhri HF, Lee MR: Treatment of atlantoaxial instability in pediatric patients. Neurosurg Focus 15(6):ECP1, 2003

116. Rao S, Yadav A, Galvan R: Posterior cervical spine stabilization under local anesthesia. J Spinal Disord 3:250-254, 1990

117. Robertson SC, Menezes AH: Occipital calvarial bone graft in posterior occipitocervical fusion. Spine (Phila Pa 1976) 23:249-255, 1998

118. Rocque BG, Kelly MP, Miller JH, Li Y, Anderson PA: Bone morphogenetic protein-associated complications in pediatric spinal fusion in the early postoperative period: an analysis of 4658 patients and review of the literature. $\mathbf{J}$ Neurosurg Pediatr 14:635-643, 2014

119. Rodgers WB, Coran DL, Emans JB, Hresko MT, Hall JE:
Occipitocervical fusions in children. Retrospective analysis and technical considerations. Clin Orthop Relat Res (364): 125-133, 1999

120. Rodgers WB, Coran DL, Kharrazi FD, Hall JE, Emans JB: Increasing lordosis of the occipitocervical junction after arthrodesis in young children: the occipitocervical crankshaft phenomenon. J Pediatr Orthop 17:762-765, 1997

121. Roy L, Gibson DA: Cervical spine fusions in children. Clin Orthop Relat Res 73:146-151, 1970

122. Rozzelle CJ, Aarabi B, Dhall SS, Gelb DE, Hurlbert RJ, Ryken TC, et al: Os odontoideum. Neurosurgery 72 (Suppl 2):159-169, 2013

123. Sakou T, Kawaida H, Morizono Y, Matsunaga S, Fielding JW: Occipitoatlantoaxial fusion utilizing a rectangular rod. Clin Orthop Relat Res (239):136-144, 1989

124. Sasaki H, Itoh T, Takei H, Hayashi M: Os odontoideum with cerebellar infarction: a case report. Spine (Phila Pa 1976) 25: 1178-1181, 2000

125. Sasso RC, LeHuec JC, Shaffrey C: Iliac crest bone graft donor site pain after anterior lumbar interbody fusion: a prospective patient satisfaction outcome assessment. J Spinal Disord Tech 18 (Suppl):S77-S81, 2005

126. Sawin PD, Traynelis VC, Menezes AH: A comparative analysis of fusion rates and donor-site morbidity for autogeneic rib and iliac crest bone grafts in posterior cervical fusions. J Neurosurg 88:255-265, 1998

127. Schultz KD Jr, Petronio J, Haid RW, Rodts GE, Erwood $\mathrm{SC}$, Alexander J, et al: Pediatric occipitocervical arthrodesis. A review of current options and early evaluation of rigid internal fixation techniques. Pediatr Neurosurg 33:169-181, 2000

128. Segal LS, Drummond DS, Zanotti RM, Ecker ML, Mubarak SJ: Complications of posterior arthrodesis of the cervical spine in patients who have Down syndrome. J Bone Joint Surg Am 73:1547-1554, 1991

129. Sethi A, Craig J, Bartol S, Chen W, Jacobson M, Coe C, et al: Radiographic and CT evaluation of recombinant human bone morphogenetic protein-2-assisted spinal interbody fusion. AJR Am J Roentgenol 197:W128-W133, 2011 (Erratum in AJR Am J Roentgenol 197:1024, 2011)

130. Shamseer L, Moher D, Clarke M, Ghersi D, Liberati A, Petticrew M, et al: Preferred reporting items for systematic review and meta-analysis protocols (PRISMA-P) 2015: elaboration and explanation. BMJ 349:g7647, 2015

131. Shimer AL, Oner FC, Vaccaro AR: Spinal reconstruction and bone morphogenetic proteins: open questions. Injury 40 (Suppl 3):S32-S38, 2009

132. Shin H, Barrenechea IJ, Lesser J, Sen C, Perin NI: Occipitocervical fusion after resection of craniovertebral junction tumors. J Neurosurg Spine 4:137-144, 2006

133. Simsek S, Yigitkanli K, Seckin H, Akyol C, Belen D, Bavbek M: Freehand C1 lateral mass screw fixation technique: our experience. Surg Neurol 72:676-681, 2009

134. Smith MD, Phillips WA, Hensinger RN: Fusion of the upper cervical spine in children and adolescents. An analysis of 17 patients. Spine (Phila Pa 1976) 16:695-701, 1991

135. Smucker JD, Rhee JM, Singh K, Yoon ST, Heller JG: Increased swelling complications associated with off-label usage of rhBMP-2 in the anterior cervical spine. Spine (Phila Pa 1976) 31:2813-2819, 2006

136. Sribnick EA, Dadashev VY, Brahma B, Wrubel DM: The use of inside-outside screws for occipitocervical fusion in pediatric patients. J Neurosurg Pediatr 10:392-397, 2012

137. Stabler CL, Eismont FJ, Brown MD, Green BA, Malinin TI: Failure of posterior cervical fusions using cadaveric bone graft in children. J Bone Joint Surg Am 67:371-375, 1985

138. Steinmetz MP, Lechner RM, Anderson JS: Atlantooccipital dislocation in children: presentation, diagnosis, and management. Neurosurg Focus 14(2):ecp1, 2003 
139. Stevenson KL, Wetzel M, Pollack IF: Delayed intracranial migration of cervical sublaminar and interspinous wires and subsequent cerebellar abscess. Case report. J Neurosurg 97 (1 Suppl): 113-117, 2002

140. Tauchi R, Imagama S, Ito Z, Ando K, Hirano K, Muramoto A, et al: Complications and outcomes of posterior fusion in children with atlantoaxial instability. Eur Spine J 21:13461352, 2012

141. Tauchi R, Imagama S, Ito Z, Ando K, Muramoto A, Matsui $\mathrm{H}$, et al: Surgical treatment for chronic atlantoaxial rotatory fixation in children. J Pediatr Orthop B 22:404-408, 2013

142. Thomas JA, Tredway T, Fessler RG, Sandhu FA: An alternate method for placement of C-1 screws. J Neurosurg Spine 12:337-341, 2010

143. Tsirikos AI, Markham P, McMaster MJ: Surgical correction of spinal deformities following spinal cord injury occurring in childhood. J Surg Orthop Adv 16:174-186, 2007

144. Tubbs RS, Beckman J, Naftel RP, Chern JJ, Wellons JC III, Rozzelle CJ, et al: Institutional experience with 500 cases of surgically treated pediatric Chiari malformation Type I. J Neurosurg Pediatr 7:248-256, 2011

145. Tubbs RS, Wellons JC III, Oakes WJ: Dolichoodontoid in a pediatric patient. Pediatr Neurosurg 37:217-219, 2002

146. Tuite GF, Veres R, Crockard HA, Sell D: Pediatric transoral surgery: indications, complications, and long-term outcome. J Neurosurg 84:573-583, 1996

147. Tuli SK, Chen P, Eichler ME, Woodard EJ: Reliability of radiologic assessment of fusion: cervical fibular allograft model. Spine (Phila Pa 1976) 29:856-860, 2004

148. U.S. Food and Drug Administration: Use of bone graft substitutes containing recombinant proteins or synthetic peptides in patients under age 18. FDA Safety Communications. (http://www.fda.gov/MedicalDevices/ Safety/AlertsandNotices/ucm430868.htm) [Accessed July 31, 2015]

149. Vaccaro AR, Chiba K, Heller JG, Patel TCh, Thalgott JS, Truumees E, et al: Bone grafting alternatives in spinal surgery. Spine J 2:206-215, 2002

150. Visocchi M, Fernandez E, Ciampini A, Di Rocco C: Reducible and irreducible os odontoideum in childhood treated with posterior wiring, instrumentation and fusion. Past or present? Acta Neurochir (Wien) 151:1265-1274, 2009

151. Wang J, Vokshoor A, Kim S, Elton S, Kosnik E, Bartkowski H: Pediatric atlantoaxial instability: management with screw fixation. Pediatr Neurosurg 30:70-78, 1999
152. Wang S, Wang C, Leng H, Zhao W, Yan M, Zhou H: Cable-strengthened $\mathrm{C} 2$ pedicle screw fixation in the treatment of congenital C2-3 fusion, atlas occipitalization, and atlantoaxial dislocation. Neurosurgery 71:976-984, 2012

153. Wills BP, Jencikova-Celerin L, Dormans JP: Cervical spine range of motion in children with posterior occipitocervical arthrodesis. J Pediatr Orthop 26:753-757, 2006

154. Yamazaki M, Akazawa T, Koda M, Okawa A: Surgical simulation of instrumented posterior occipitocervical fusion in a child with congenital skeletal anomaly: case report. Spine (Phila Pa 1976) 31:E590-E594, 2006

155. Yerramneni VK, Chandra PS, Kale SS, Lythalling RK, Mahapatra AK: A 6-year experience of 100 cases of pediatric bony craniovertebral junction abnormalities: treatment and outcomes. Pediatr Neurosurg 47:45-50, 2011

156. Zenonos G, Jamil O, Governale LS, Jernigan S, Hedequist D, Proctor MR: Surgical treatment for primary spinal aneurysmal bone cysts: experience from Children's Hospital Boston. J Neurosurg Pediatr 9:305-315, 2012

157. Zhang HQ, Lin MZ, Guo HB, Ge L, Wu JH, Liu JY: Onestage surgical management for tuberculosis of the upper cervical spine by posterior debridement, short-segment fusion, and posterior instrumentation in children. Eur Spine J 22:72-78, 2013

\section{Disclosure}

The authors report no conflict of interest concerning the materials or methods used in this study or the findings specified in this paper.

\section{Author Contributions}

Conception and design: Tuite, Rodriguez, Carey. Acquisition of data: Tuite, Reintjes, Amankwah. Analysis and interpretation of data: Tuite, Reintjes, Amankwah. Drafting the article: Tuite, Reintjes, Amankwah. Critically revising the article: all authors. Reviewed submitted version of manuscript: all authors. Approved the final version of the manuscript on behalf of all authors: Tuite. Statistical analysis: Amankwah. Study supervision: Tuite.

\section{Correspondence}

Gerald F. Tuite, Neuroscience Institute, All Children's Hospital, 601 5th St. South, Ste. 511, St. Petersburg, FL 33701. email: geraldtuite@gmail.com. 